\title{
Acetazolamide therapy for hypokalemic alkalosis in Bartter syndrome
}

\author{
Farahnak Assadi* ${ }^{*}$ \\ Department of Pediatrics, Division of Nephrology, Rush University Medical Center, 445 E. North Water Street, Suite 1804, Chicago, \\ Illinois, USA
}

\section{A R T I C L E I N F O}

\begin{tabular}{l} 
Article Type: \\
Editorial \\
\hline
\end{tabular}

\section{Article History:}

Received: 3 May 2019

Accepted: 4 June 2019

Published online: 19 June 2019

\begin{abstract}
Implication for health policy/practice/research/medical education:
There is no information available on the efficacy of acetazolamide on the management of severe hypokalemic alkalosis refractory to the standard therapy. A benefit from acetazolamide appears to be apparent in the management of hypokalemic alkalosis in patients with Barter syndrome.

Please cite this paper as: Assadi F. Acetazolamide therapy for hypokalemic alkalosis in Bartter syndrome. J Renal Inj Prev. 2019; 8(3): 169-171. DOI: 10.15171/jrip.2019.31.
\end{abstract}

Keywords: Acetazolamide, Bartter Syndrome, Hypokalemia, Metabolic alkalosis
$\mathrm{B}$ artter syndrome is an autosomal recessive kidney disorder characterized by hypokalemia, metabolic alkalosis, and normal blood pressure (1). The syndrome is associated with mutations in $\mathrm{Na}^{+}, \mathrm{K}^{+}, 2 \mathrm{Cl}^{-}$ system also called as the $\mathrm{Na}^{+}-\mathrm{K}^{+}-2 \mathrm{Cl}^{-}$cotransporter in the tick ascending loop of Henle (2). Under normal conditions, once the $\mathrm{Na}^{+}, \mathrm{K}^{+}, 2 \mathrm{Cl}-$ is transported into the apical membrane of the tubule cells, $\mathrm{Na}^{+}$is transported by active $\mathrm{Na}^{+} / \mathrm{K}^{+} /$ATPase, and $\mathrm{Cl}^{-}$is passed by diffusion across the basolateral $\mathrm{Cl}^{-}$channels. However, $\mathrm{K}^{+}$ions, is transported back through the apical $\mathrm{K}+$ into the lumen, establishing a positive charge between the interstitial compartment and tubule lumen. This charge gradient is necessary for the reabsorption of both $\mathrm{Ca}^{++}$and $\mathrm{Mg}^{++}$ions.

Impaired operation of any component of this reabsorption system can result in clinical manifestation of Bartter syndrome. Inactivation of this transport system can lead to reduced $\mathrm{K}^{+}$, and $\mathrm{Cl}^{-}$, and $\mathrm{Na}^{+}$reabsorptions in the ascending loop of Henle, as well as impaired renal ability to concentrate urine, leading to significant polyuria and potential for severe life-threatening dehydration specially in infants and toddlers if do not receive adequate water. Furthermore, the increased $\mathrm{Na}^{+}$delivery to distal nephron and collecting duct promotes $\mathrm{K}^{+}$and $\mathrm{H}^{+}$ions excretion into the lumen by principal cells in exchange for $\mathrm{Na}^{+}$reabsorption, leading to hypokalemia and metabolic alkalosis (3).

To date, five types of Bartter syndrome have been identified through genetic analysis. The neonatal Batter syndrome is associated with mutations in SLC12A1 (NKCC2) (type 1) $(4,5)$ or ROMK/KCNJ1 (type 2) $(6,7)$ protein genes and is manifested during neonatal period by polyuria, severe dehydration, polydipsia, hypokalemic alkalosis, hypercalciuria, nephrocalcinosis, kidney stones, and may progress to renal failure.

Classic Bartter syndrome (type 3) is due to mutations in $C L C N B K$ gene, located in the thick ascending limb of the Henle (7). Patients with classic Bartter syndrome usually presents during school age with symptoms that are similar to those patients receiving furosemide diuretic. Patients with type 3 Bartter syndrome also have polydipsia and polyuria, hypokalemia, alkalosis, normal blood pressure and failure to thrive, but or mildly elevated urinary $\mathrm{Ca}^{++}$ excretion without the tendency to develop nephrolithiasis. The diagnosis is established by increased plasma renin activity (PRA), aldosterone levels and over production renal prostaglandins. High urinary $\mathrm{K}^{+}, \mathrm{Na}^{+}, \mathrm{Cl}, \mathrm{Ca}^{++}$and $\mathrm{Mg}^{+}$levels despite of low serum $\mathrm{Na}^{+}, \mathrm{K}^{+}$, and $\mathrm{Cl}^{-}$and $\mathrm{Mg}^{++}$ values are usually found. The hypercalciuria in Bartter syndrome is secondary to impaired furosemide-delicate transport system in the ascending loop of Henle.

The increased PRA and aldosterone level is secondary to hyperplasia of the juxtaglomerular apparatus $(6,8)$.

Type 4 Batter syndrome is caused by mutations in gene $B S N D$ is also associated with sensorineural deafness (9) while type 5 Bartter syndrome is caused by mutations in gene CASR and is associated with autosomal dominant hypokalemia (10). 
Gitelman syndrome, which is a subset of classic Bartter syndrome is caused by mutations in the SLC12A3 gene resulting in an impaired function of the thiazide- $\mathrm{Na}^{+}-\mathrm{Cl}^{-}$ transport mechanism also known as NCCT, located in the distal convoluted tubules, which is responsible for the transport of $\mathrm{Na}^{+}, \mathrm{K}^{+}, \mathrm{Cl}^{-}, \mathrm{Ca}^{++}$, and $\mathrm{Mg}^{++}$(11-14).

Clinical signs of Gitelman syndrome include hypokalemic alkalosis with normal blood pressure, hypomagnesemia, and hypocalciuria. The hypercalciuria in Gitelman syndrome is influenced by defective thiazidefinely tuned transport system in the convoluted tubules $(15,16)$.

Early diagnosis and appropriate treatment of fluidelectrolyte disorders in infants and young children may improve growth and prevent or retard the disease progression to kidney failure.

The standard therapy includes KCL supplementation, prostaglandin E inhibitors (NSAIDS), angiotensinconverting enzyme inhibitors (ACEI) such as enalapril, and aldosterone antagonists such (spironolactone or amiloride) (17-21).

However, hypokalemic alkalosis persists in majority of patients despite of combination therapy with $\mathrm{K}^{+}$ sparing diuretics, angiotensin-converting enzyme inhibitors (ACEI), and nonsteroidal anti-inflammatory drugs (NSAIDs). Acetazolamide, a carbonic anhydrase inhibitor, has been used frequently and effectively for the management of hypokalemic alkalosis as a result of loop diuretics administration, especially in critically ill patients with congestive heart failure (22-25).

There is no information available on the efficacy of acetazolamide on the management of severe hypokalemic alkalosis refractory to the standard therapy. A benefit from acetazolamide appears to be apparent in the management of hypokalemic alkalosis in patients with Barter syndrome. Acetazolamide, prevents reabsorption of sodium bicarbonate in the proximal tubule, thereby causing bicarbonate wastage (26).

The low cost, limited side effects and the ease of administration are compelling evidence to consider acetazolamide for the treatment of hypokalemic alkalosis in patients with Batter syndrome unresponsive to the conventional therapy.

\section{Author's contribution}

FA is the single author of the paper.

Conflicts of interest

The author declare no conflict of interest.

\section{Ethical considerations}

Ethical issues (including plagiarism, data fabrication, double publication) have been completely observed by the author.

\section{Funding/Support}

None.

\section{References}

1. Simon DB, Karet FE, Hamdam JM, DiPietro A, Sanjad SA, Lifton RP. Bartter's syndrome, hypokalemic alkalosis with hypercalciuria, is caused by mutations in the Na-K2Cl cotransporter NKCC2. Nat Genet. 1996; 13:183-8. doi: 10.1038/ng0696-183

2. Ares GR, Gaceres PS, Ortiz PA. Molecular regulation of NKCC2 in the thick ascending limb. Am J Physiol Renal Physiol. 2011; 301:F1143-F1159. doi: 10.1152/ ajprenal.00396.2011.

3. Lee BH, Cho HY, Lee H, Han KH, Kang HG, Ha IS, et al. Genetic basis of Bartter syndrome in Korea. Nephrol Dial Transplant. 2012; 27:1516-21. doi: 10.1093/ndt/gfr475.

4. Carmosino M, Procino G, Svelto M. $\mathrm{Na}^{+}-\mathrm{K}^{+}-2 \mathrm{Cl}^{-}$ cotransporter type 2 traffecking and activity: the role of interacting proteins. Bil Cell. 2012; 104:201-12. doi: 10.1111/boc.201100049.

5. Dane B, Yayla M, Dane C, Cetin A. Prenatal diagnosis of Bartter syndrome with biochemical examination of amniotic fluid: case report. Fetal Diag Ther. 2007; 22:206-8. doi: $10.1159 / 000098719$.

6. Komhoff M, Laghmani K. Pathophysiology of antenatal Bartter's syndrome. Curr Opin Nephrol Hypertens. 2017; 419-25. doi: 10.1097/MNH.0000000000000346.

7. Cunha TDS, Heilberg IP. Bartter syndrome: causes, diagnosis, and treatment. Int J Nephrol Renovasc Dis. 2018; 11:291-301. doi: 10.2147/IJNRD.S155397.

8. Bartter FC, Pronove P, Gill JR, MacCardle RC. Hyperplasia of juxtaglomerular complex with hyperaldosteronism and hypokalemic alkalosis: a new syndrome. Am J Med.1962; 33:811-28.

9. Zaffanello M, Taranta A, Palma A, Bettinelli A, Marseglia GL, Emma F. Bartter syndrome:report of two new cases. Pediatr Nephro. 2006; 21:766-70. doi: 10.1007/s00467-0060090-x.

10. Vezzoli G, Arcidiacono T, Paloschi V, Terranegra A, Biasion R, Weber G, et al. Autosomal dominant hypocalcemia with mild type 5 Bartter syndrome. J Nephrol. 2006; 19:525-8.

11. 11.Naesens M, Steels P, Verberckmoes R, Vanrenterghem Y, Kuypers D. Bartter's and Gitelman's syndromes: from gene to clinic. Nephron Physiol.2004; 96:65-78. doi: $10.1159 / 000076752$.

12. Nakhoul F, Nakhoul N, Dorman E, Berger L, Skorecki K, Magen D. Gitelman's syndrome: am pathophysiological and clinical updates. Endocrine (Review). 2012; 41:53-7. doi: 10.1007/s12020-011-9556-0.

13. Seyberth HW, Weber S, Komhoff M. Bartter's and Gitelman's syndrome. Curr Opin Pediatr. 2017; 29:179-186. doi: $\quad 10.1097 / M O P .0000000000000447$.

14. Fremont OT, Chan JC. Understanding Bartter syndrome and Gitleman syndrome. World J Pediatr. 2012; 8:25-30. doi: 10.1007/s12519-012-0333-9.

15. Fulchiero R, Seo-Mayer P. Bartter syndrome and Gitelman syndrome. Pediatr Clin North Am. 2019; 66:121-34. doi: 10.1016/j.pcl.2018.08.010.

16. Walsh PR, Tse Y, Ashton E, Lancu D, Jenkins L, Bienias $\mathrm{M}$, et al. Clinical and diagnostic features of Bartter and Gitelman syndromes. Clin Kidney J. 2018; 11:3012-9. doi: $10.1093 / \mathrm{ckj} / \mathrm{sfx} 118$.

17. Verberckmoes R, Van Damme B, Clement J, Amery 
A, Michielsen P. Bartter's syndrome with hyperplasia of renomedullary cells: successful treatment with indomethacin,. Kidney Int.1976; 9:302-7. doi:10.1038/ ki.1976.33.

18. Griffing GT, Komanicky P, Aurecchia SA, Sindler BH, Melby JC. Amiloride in Bartter's syndrome. Clin Pharmacol Ther. 1982; 31:713-8. doi: 10.1038/clpt.1982.100.

19. Hene RJ, Koomans HA, Dorhout Mees EJ, vd Stolpe A, Verhoef GE, Boer P. Correction of hypokalemia in Bartter's syndrome by enalepril. Am J Kidney Dis. 1978; 9:200-205.

20. Gasongo G, Greebaum LA, Neil O, Kwon T, Macher MA, Maisin A, et al. Effect of nonsteroidal anti-inflammatory drugs in children with Bartter syndrome. Pediatr Nephrol. 2019; 34:679-684. doi: 10.1007/s00467-018-4135-8.

21. Nascimento CLP, Garcia CL, Schvartsman BGS, Vaisbich MH. Treatment of Bartter syndrome, unsolved issue. J Pediatr. 2014; 90:512-7. doi: 10.1016/j.jped.2014.01.012.
22. Andrews MG, Johnson PN, Lammers EM, Harrison DL, Miller JL. Acetazolamide in critically ill neonates with metabolic alkalosis. Ann Pharmacother. 2013; 47:1130-5. doi: $10.1177 / 1060028013500468$.

23. Lopez C, Alcaraz AJ, Toledo B, Cortejoso L, Gil-Ruitz MA. Acetazplamide therapy for metabolic alkalosis in pediatric intensive care patients. Pediatri Crit Care Med. 2016;17:e551-8.doi:10.1097/PCC.0000000000000971.

24. Peixoto AJ, Alpern RJ. Treatment of severe metabolic alkalosis in a patient with congestive heart failure. Am J Kidney Dis.2013; 61:822-7. doi: 10.1053/j.ajkd.2012.10.028.

25. Bar A, Cies J, Stapleton K, Tauber D, Chopra A, Shore PM. Acetazolamide therapy for metabolic alkalosis in critically ill pediatric patients. Pediatr Crit Care Med. 2015; 16:3e440. doi: 10.1097/PCC.0000000000000313.

26. Preisig PA, Toto RD, Alpern RJ. Carbonic anhydrase inhibitors. Renal Physiol.1987; 10:136-59.

Copyright (c) 2019 The Author(s); Published by Nickan Research Institute. This is an open-access article distributed under the terms of the Creative Commons Attribution License (http://creativecommons.org/licenses/by/4.0), which permits unrestricted use, distribution, and reproduction in any medium, provided the original work is properly cited. 